\title{
Gender Specific Preferences Towards Anthropomorphic AI Devices and Robots
}

\author{
Corina Pelau ${ }^{1}$, Miruna Niculescu ${ }^{2}$ and Irina Bojescu ${ }^{3}$ \\ 1)2)3) The Bucharest University of Economic Studies, Bucharest, Romania. \\ E-mail: corina.pelau@fabiz.ase.ro; E-mail: miruna_niculescu@yahoo.com; \\ E-mail: irina0927@yahoo.com
}

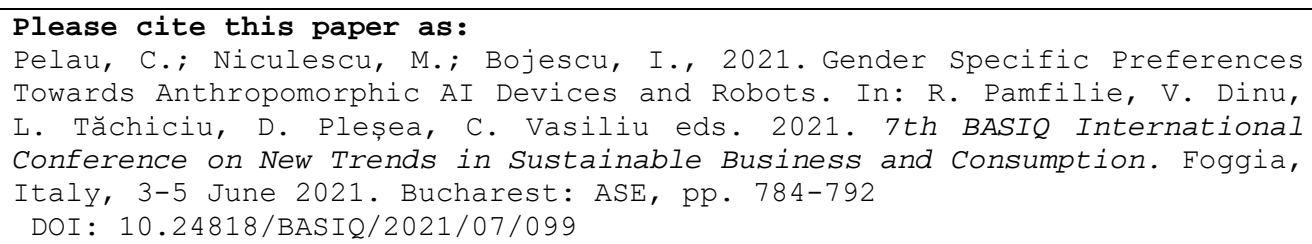

\begin{abstract}
In recent years, artificial intelligence has changed the way people interact with each other or with technology. The discussion on the spectacular evolution of this phenomenon is more actual and present than ever because of the fact that devices equipped with artificial intelligence are more frequently present in lives of consumers, impacting their daily activities. The objective of this paper is to examine the gender specific perceptions and preferences towards anthropomorphic and empathetic characteristics of AI devices and robots. Anthropomorphic characteristics of an AI device or robot can have a positive influence on consumer's perception towards them and towards the decision of buying these products. This paper presents the way in which AI impacts the emotional perception of consumers and the differences of attitude between men and women towards the interaction with robots and AI devices. The empirical part of this paper includes the results of a research regarding the differences of perception and preference of consumers, towards the anthropomorphic characteristics of AI devices and robots, depending on gender. Using the discriminant analysis in SPSS 20, we have shown that men consider AI devices and robots more entertaining, while women appreciate more their empathetic human-like interaction and behavior. This result is important for the marketing communication when AI devices and robots are marketed. In the marketing communication addressed to men, features like the entertaining role of AI devices should be addressed, while in women specific communication channels the empathetic human-like interaction should be emphasized.
\end{abstract}

\section{Keywords}

Artificial intelligence, robots, consumers, anthropomorphic, empathy, gender, acceptance.

DOI: 10.24818/BASIQ/2021/07/099

\section{Introduction}

In the last decade, artificial intelligence has hugely changed the interaction between humans and also the way we interact with technology. Research in the field of information and communication technology has focused on innovation, which allows companies to develop and implement effective consumer-oriented strategies (Sun, 2006). In recent years, the business environment has become more competitive, interconnected and transparent, making companies to focus on offering memorable experiences to their consumers in order to be able to differentiate and to build a solid competitive position (Banacu, et al., 2019; Berry, et al., 2002; Schmitt, 1999; Pine and Gilmore, 1998). This challenge is relevant for all sector and extremely important to the services industry (Markovic, et al., 2018; Dabija and Babut, 2019; Pelau and Acatrinei, 2019) because of the need of interaction between the companies' employees and consumers (Grönroos, 2006). Consumers' satisfaction and their affective commitment to brands can be increased by a favorable brand experience, which strengthens 
brand equity and improves the quality of the relationship between brand and customer (Lin, 2015; Yao, et al., 2013; Iglesias, et al., 2011; Brakus, et al., 2009). According to Brakus, et al., (2009), brand experience is composed of four distinct dimensions: sense, affection, intellectual and behavior. Recent researchers suggest that the sense dimension is particularly relevant and important in services settings (Lin, 2015; Goldkuhl and Styvén, 2007).

Recent statistics suggest that around $86 \%$ of retail marketing programs have launched plans to invest in artificial intelligence in the next years (Persado, 2017; Mitrut, et al., 2015). Despite that, people may oppose to using robots for delivering services because of different reasons like lacking human touch or ethical concerns with the potential growth of unemployment rate caused by the entering of robots on the labor market (Lu, et al., 2019). According to Business Insider (2015) the demand for service robots has highly increased reaching a global market of 1.5 billion USD by 2019 . This will increase even more because of the need for social distancing, determined by the COVID-19 pandemic. In the hospitality industry, the customer experience optimization will continue to involve the infusion of technology melted into various services' facets ( $\mathrm{Lu}$, et al., 2019).

Our paper is structured as follows. In the first part of the paper there are presented the theoretical aspects regarding the use of AI devices and robots, especially the way in which anthropomorphic characteristics can change people's perspective about them as well as the constructs ,anthropomorphic" and „empathy". In the empirical part of the paper we will analyze the way in which men and women perceive the anthropomorphic and empathetic AI devices and robots. We will focus on the way in which these characteristics influence their preferences, their choices and opinions. There are presented the results of a comparative research between men and women' perception and preferences related to anthropomorphic characteristics of AI devices and robots and the possibility of buying such products.

\section{Literature review}

\section{Anthropomorphic condition of AI devices and robots}

The marketing communication strategies, consumer experience and service delivery have been highly influenced in the last decades by the development of the technology. Artificial intelligence and robots have become more present in the market, companies have begun to invest more resources in developing artificial intelligence programs in order to offer unique experiences to consumers. However, among the challenges that arise are the lack of human touch and also the fear that humans will be replaced and that the unemployment rate will grow (Lu et al., 2019). Anthropomorphic characteristics change the perspective of the absence of human interaction, because humanized brands and robots are perceived as similar entities to humans, capable of showing emotions and feelings, expressing concern and trust in a relationship (Golossenko, et al., 2020).

Anthropomorphic characteristics are described as specific attributes that define human beings, which are usually perceived as unique and particular for individuals that have the capacity to have psychological as well as emotional states (Golossenko, et al., 2020). Consumers tend to perceive other entities and products in an anthropomorphic even human like manner (Aggarwal and McGill, 2012; Cantaragiu and Ghinea, 2020; Golossenko, et al., 2020; Stanciu, et al., 2019). This perception is highly influenced by the marketing communication strategies developed to sustain it in order to humanize their brand and strengthen their place in the market. The capacity to speak, have emotions, express wishes or desires, the ability to develop a personality, but also the presence of similarities between the human appearance like body parts and the robot that possesses artificial intelligence may indirectly influence the consumers' perception associated to a company (Kim and McGill, 2011; Puzakova, et al., 2013; Golossenko, et al., 2020). These similar characteristics to those which are specific for humans are being used in such mixture that they consolidate the position of a brand or a product itself, because consumers tend to express a more enthusiastic attitude regarding anthropomorphized brands (Aggarwal and McGill, 2007; Golossenko, et al., 2020) and they easily tend to interact and build relationships with the providing company (Ahn, et al., 2014; Fournier and Alvarez, 2012; Serban, et al., 2019; Golossenko, et al., 2020).

Anthropomorphism plays an important role in observing the relation between humans and technology, mainly represented by robots possessing artificial intelligence (van Doorn, et al., 2017; Lu, et al., 2019). 
Products with human features have a positive influence on the consumers' perception and on the buying decision (Kim and McGill, 2011; Landwehr, et al., 2011, Lu, et al., 2019). These kind of products are remembered as familiar and comfortable, because their characteristics are stored in the memory with the help of the similarities to human attributes (Lu, et al., 2019). The effectiveness of anthropomorphism appears mainly when the robots, devices or the sold products reveal human intelligence. But on the other hand, intelligent robots with similar appearance to humans may be considered a threat for individuals' identity, as well as disruptive to the uniqueness of humans. People are afraid of losing their specific attributes and their distinctiveness, and as a result they perceive intolerable this thought $(\mathrm{Lu}$, et al., 2019). Nevertheless anthropomorphism is considered the lead to the interaction between humans and computers, helping at designing the appearance of robots and the interfaces for users. It influences the relations and the social actions. User friendly interfaces and the possibility to personalize the experience with the device could be made by the consumer as well. People tend to personalize their devices in order to gain exclusiveness and to create a bound between them, reflecting that kind of interaction that the user requires with the machine (Wang, 2017).

\section{Empathetic AI devices}

Empathy is defined as the awareness of a person and the capacity of understanding and knowing how to react in a favorable manner to others' feelings and thoughts (Iglesias, et al., 2019). It is considered the core of the relationship between a consumer and a representative of a company. For example an employee working in providing services influences the whole interaction between the company and the customers, as he/ she can make them either favorable or not for the company (Aggarwal, et al., 2005; Giacobbe, et al., 2006; Iglesias, et al., 2019). Empathy is a mandatory skill for the employees that are supposed to interact with customers (Ahearne, et al., 2007; Pilling and Eroglu, 1994; Iglesias, et al., 2019), because they are the image of the company and they have the power to influence the perception of the clients.

Perceived empathy refers to a person's impression that the other communication partner shares and understands his or her feelings and that the listener places himself/ herself in their shoes (Lazarus, 1991; Simon, 2013). Customer engagement to a company could be influenced by the perceived empathy and it is defined as a psychological process which involves a continuous interaction between the person and the preferred service or good offered by the company (Bowden, 2009; Brodie, et al., 2011; Kim and Baek, 2018). However nowadays the interaction is no longer limited to human contacts, as the possibility to interconnect with a company through mobile apps with the help of artificial intelligence or robots exists (Kimand Baek, 2018). Mobile apps play an essential role in the digital era because they are used as a communication channel between the company and the customers and they contribute to brand loyalty growth and to developing consistent connections with targeted people (Wang, et al., 2015; Kim and Baek, 2018). In this way, empathy may be perceived not only through face-to-face contacts, but also through online channels by using computer communications. As in the online environment there are no non-verbal signs and communication, such as eye contact or gestures, as users tend to shape their emotions in styles and texts that reflect what they feel. Customers are up to perceive the empathy and the personal interactions that occur through intelligent devices trying to manifest a friendly position (Simon, 2013).

Positive service experiences with a company might arise for customers either through the contact with employees or through devices or robots that should be programmed to reflect an empathic attitude. In both cases the experience may focus on understanding and taking into consideration the client's expectations and may have the possibility to respond quickly and with efficiency to their demands. An empathic position may influence the customers and might lead to an increase of the satisfaction and engagement with the brand. Moreover, empathy has an important role in giving personalized experiences to each customer and this influences their satisfaction. Algorithms that are highly orientated to customer' satisfaction and that present solutions and offers that seem unique and especially dedicated to each customer, have more efficiency in obtaining the customers gratitude. After all, the empathy might lead to customer brand experience, because when customers feel that their needs are understood and fulfilled then their experience with the brand is perceived in a better way (Iglesias, et al., 2019).

The use of artificial intelligence has a growing positive impact on the companies' profits and on the sustainability of businesses (Busu, 2019; Cioaca, et al., 2020), but in the same time people are more 
and more afraid of losing their jobs because several tasks performed nowadays by humans, will be replaced by artificial intelligence and robots (Huang and Rust, 2018). The main reason for not accepting AI devices and robots in their lives is caused by this uncertainty. Despite this, according to previous researches, the fears that people have by using AI devices and robots are reduced due to the benefits obtained from their use, the influence of the social circle (Pelau, et al., 2021a) and also because of their contribution to the increasing of the quality of life (Ene and Bojescu, 2020). There are no major differences in the perception of AI for men and women. Women are more willing to accept AI devices and robots in their lives because of a higher efficiency, learning processed and hedonic pleasure, view while for men, the quality of life improvement is the most important argument of accepting AI devices and robots in their lives (Ene and Bojescu, 2020).

\section{Research methodology}

The objective of our research is to determine the gender specific perceptions and preferences towards anthropomorphic and empathetic characteristics of AI devices and robots. In comparison to previous researches where few gender specific differences have been found related to the functionality and efficiency of AI, when it comes to emotional components there are differences in perception between men and women. Data collection for this research has been carried out based on an online survey which took place in September 2020. A number of 76 valid responses have been received (43 women and 33 men).

In this research there have been analyzed 21 items for the following constructs: anthropomorphic characteristics of AI devices (5 items adapted after Lu et al. 2019), interaction abilities of AI devices (6 items adapted after Bruner, 2019; Chun, et al. 2017; Kim, et al., 2017), ability of AI to show empathy (10 items adapted after Bruner, 2019; Kim, et al., 2017; Kirmani, et al., 2017; Bagchi and Ince, 2016). The validity of the items is given by a Cronbach-Alpha value of $0.940(\mathrm{~F}=25.32, \mathrm{p}=0.000)$. The results have been analyzed with the help of the discriminant analysis in SPSS 20.0.

\section{Results and discussions}

The results of the research show that the main differences between men and women are perceived for the human-AI interaction and for some anthropomorphic features. The results of our discriminant analysis can be observed in table no. 1 .

For the anthropomorphic characteristics of AI devices, both genders have an average evaluation of AI devices having a mind of their own $\left(\mathrm{M}_{\mathrm{women}}=4.02, \mathrm{M}_{\mathrm{men}}=3.81, \mathrm{~F}=0.195, \mathrm{p}=0.660>0.10\right)$, but none of them believe that $\mathrm{AI}$ have consciousness $\left(\mathrm{M}_{\mathrm{women}}=2.86, \mathrm{M}_{\mathrm{men}}=2.54, \mathrm{~F}=0.537, \mathrm{p}=0.466>0.10\right)$ or their own free will $\left(\mathrm{M}_{\text {women }}=2.76, \mathrm{M}_{\mathrm{men}}=2.63, \mathrm{~F}=0.099, \mathrm{p}=0.754>0.10\right)$. The average values of these 3 items are close to each other and the main idea reflected by the answers is that humanlike characteristics of AI devices do not have the capacity to influence the perception of women or men. Regarding the potential ability of robots of experiencing emotions $\left(\mathrm{M}_{\mathrm{women}}=2.93, \mathrm{M}_{\mathrm{men}}=2.06, \mathrm{~F}=5.007, \mathrm{p}=0.028<0.05\right)$ and the existence of similarities between $\mathrm{AI}$ and humans $\left(\mathrm{M}_{\mathrm{women}}=2.46, \mathrm{M}_{\mathrm{men}}=1.75, \mathrm{~F}=4.051\right.$, $\mathrm{p}=0.048<0.05$ ), the average scores of women and men show that both disagree with these statements. However, there is a significant difference related to the fact that women are not as convinced as men, because the women's average scores are higher. A reason could be that women tend to show more empathy and think more based on their emotions.

Regarding the interaction abilities of AI devices, there are significant differences of perspectives in finding it enjoyable $\left(\mathrm{M}_{\mathrm{women}}=4.16, \mathrm{M}_{\text {men }}=4.90, \mathrm{~F}=4.038, \mathrm{p}=0.048<0.05\right)$, fun $\left(\mathrm{M}_{\mathrm{women}}=4.34, \mathrm{M}_{\text {men }}=5.21\right.$, $\mathrm{F}=5.383, \mathrm{p}=0.023<0.05)$, good $\left(\mathrm{M}_{\text {women }}=4.32, \mathrm{M}_{\mathrm{men}}=5.03, \mathrm{~F}=3.458, \mathrm{p}=0.067<0.10\right)$ and pleasant $\left(\mathrm{M}_{\mathrm{women}}=4.04, \mathrm{M}_{\mathrm{men}}=4.84, \mathrm{~F}=3.861, \mathrm{p}=0.053<0.10\right)$, having all scores above the average. The preferences are higher in the case of men, who find more satisfactory the communication with robots and devices. This could be influenced by the fact that men are more pragmatic compared to women and through their everyday life and jobs they could benefit more from the evolution of technology, having the chance to interact more with this kind of devices. Regarding feelings and developing an emotional connection with the robots, both women and men don't agree with the potential proposed scenarios. 
There is no significant difference between the average scores. A reason for these results could be the fact that people are not ready for accepting such developments or novelties, as having a relationship based on humanlike characteristics with AI devices.

Table no. 1. Gender specific differences related to AI devices

\begin{tabular}{llcccc}
\hline Var. & & \multicolumn{1}{c}{ Item } & $\begin{array}{c}\text { Aver- } \\
\text { age } \\
\text { women }\end{array}$ & $\begin{array}{c}\text { Aver- } \\
\text { age } \\
\text { men }\end{array}$ & F \\
A1 & AI devices have a mind of their own. & 4.02 & 3.81 & .195 & .660 \\
\hline A2 & AI devices have consciousness. & 2.86 & 2.54 & .537 & .466 \\
\hline A3 & AI devices have their own free will. & 2.76 & 2.63 & .099 & .754 \\
\hline A4 & AI devices will experience emotions. & 2.93 & 2.06 & 5.007 & .028 \\
\hline A5 & AI devices are like humans & 2.46 & 1.75 & 4.051 & .048 \\
\hline In1 & To what extent is interaction with the robot enjoyable & 4.16 & 4.90 & 4.038 & .048 \\
\hline In2 & To what extent is the interaction with the robot fun & 4.34 & 5.21 & 5.383 & .023 \\
\hline In3 & To what extent is the interaction with the robot good & 4.32 & 5.03 & 3.458 & .067 \\
\hline In4 & To what extent do you like the interaction with robot & 4.04 & 4.84 & 3.861 & .053 \\
\hline In5 & I felt emotionally involved with the robot & 2.65 & 2.69 & .013 & .909 \\
\hline In6 & I found the interaction with the robot moving & 3.25 & 3.24 & .001 & .977 \\
\hline E01 & The interaction with the robot affected me emotionally & 2.86 & 2.18 & 2.586 & .112 \\
\hline E02 & I was able to connect with the robot emotionally & 2.46 & 2.00 & 1.601 & .210 \\
\hline E03 & I feel that the relationship to the robot is honest & 3.34 & 3.51 & .119 & .731 \\
\hline E04 & I feel that the relationship to the robot is sincere & 3.44 & 3.60 & .115 & .736 \\
\hline E05 & I feel that the relationship to robot is not manipulative & 3.69 & 3.54 & .121 & .729 \\
\hline E06 & I feel that the relationship to the robot is trustworthy & 3.09 & 4.12 & 5.233 & .025 \\
\hline E07 & To what extent do you believe the robot is caring & 2.55 & 2.57 & .002 & .967 \\
\hline E08 & To what extent do you believe the robot is friendly & 3.67 & 3.90 & .252 & .617 \\
\hline E09 & To what extent do you believe the robot is kind & 3.32 & 2.96 & .611 & .437 \\
\hline E10 & To what extent do you believe the robot is warm & 2.53 & 2.60 & .029 & .866 \\
\hline
\end{tabular}

For the ability of AI devices and robots to show empathy, there is only one item, which reflects a notable difference. There is a significant higher belief in the case of men concerning the reliability of the relation with a robot. The score of $\operatorname{men}\left(\mathrm{M}_{\text {men }}=4.12, \mathrm{M}_{\text {women }}=3.09, \mathrm{~F}=5.233, \mathrm{p}=0.025<0.05\right)$ is higher than the average, which reflects that men trust the robots and their capacity of helping people and therefore men praise the relationship based on the advantages that it involves. The items which concern the emotional effect produced after having an interaction with a robot $\left(\mathrm{M}_{\text {women }}=2.86, \mathrm{M}_{\text {men }}=2.18\right.$, $\mathrm{F}=2.856, \mathrm{p}=0112>0.10)$, the ability of emotionally connecting with an AI device $\left(\mathrm{M}_{\mathrm{women}}=2.46\right.$, $\mathrm{M}_{\text {men }}=2.00, \mathrm{~F}=1.601, \mathrm{p}=0.210>0.10$ ), the capacity of robots of expressing the feeling of caring $\left(\mathrm{M}_{\text {women }}=2.55, \mathrm{M}_{\mathrm{men}}=2.57, \mathrm{~F}=0.002, \mathrm{p}=0.967>0.10\right)$ and being warm $\left(\mathrm{M}_{\mathrm{women}}=2.53, \mathrm{M}_{\mathrm{men}}=2.60\right.$, $\mathrm{F}=0.029, \mathrm{p}=0.866>0.10$ ) show a low affection or enthusiasm in their behaviour below the average score. There is no remarkable distinction, both categories confirm their position about robots and about the fact that they consider the AI devices incapable of possessing human-like feelings and therefore could not be treated as such. The honesty $\left(\mathrm{M}_{\mathrm{women}}=3.34, \mathrm{M}_{\mathrm{men}}=3.51, \mathrm{~F}=0.119, \mathrm{p}=0.731>0.10\right)$ and sincerity $\left(\mathrm{M}_{\text {women }}=3.44, \mathrm{M}_{\text {men }}=3.60, \mathrm{~F}=0.115, \mathrm{p}=0.736>0.10\right)$ of robots is believed to be moderate by both categories, having scores slightly above average. The manipulation is not considered a habit of robots $\left(\mathrm{M}_{\text {women }}=3.69, \mathrm{M}_{\text {men }}=3.54, \mathrm{~F}=0.121, \mathrm{p}=0.729>0.10\right)$, having average scores. People do not seem to perceive any threat concerning the possibility of being manipulated in the interaction with AI devices. The average scores reflect that kindness $\left(\mathrm{M}_{\mathrm{women}}=3.32, \mathrm{M}_{\mathrm{men}}=2.96, \mathrm{~F}=0.611, \mathrm{p}=0.437>0.10\right)$ is the only quality that might be considered appropriate to be found in robots in comparison to other characteristics, which are specific for human, and hence not attributed to devices. The scores indicate that people might appreciate this type of behaviour also in the case of robots, taking into consideration that they could help people without expecting praise or a reward. 


\section{Conclusions}

The results of our research show that there are slight differences in the perceptions and preferences of men and women regarding anthropomorphic and empathetic characteristics of AI devices and robots. What is interesting to observe is that even though women tend to be a little more optimistic and open about the potential capacity of robots of experiencing emotions and tend to accept easier the fact that AI devices could be similar to humans, they are not as convinced as men are when it comes to the things that characterize the interaction with such gadgets. Men appreciate more the relationship with robots and consider them pleasant, entertaining and satisfactory. However, the average scores illustrate that the anthropomorphic characteristics of AI devices do not have a significant impact on the perception of persons. Another important aspect is that men have more confidence in AI devices and rely more on this interaction. On the other side, women tend to be more reluctant, having average scores, which could reflect a lack of reliance and indecision. Both categories show hesitation towards the ability of AI gadgets of understanding and sharing feelings with others, neither men, nor women take into consideration the possibility of being involved emotionally in the interaction with such devices and they do not consider that their feelings could be influenced by robots. Moreover, both genders disagree with the fact that AI devices could have independent thinking, spontaneity or awareness. In our future research, we aim to investigate further the relations between the emotional sides of the human-AI interaction as well as the integration of robots in the present society. Until now, our studies on the perception of AI devices did not show significant differences on efficiency, learning processes and acceptance of AI devices and robots, but this research emphasizes that the emotional interactive part is perceived different by genders. As a practical implication, this result will impact the way in which interaction between consumers and AI devices will be designed for the future. As men find interaction with AI better and more enjoyable, it is more likely that they will accept easier the communication and interaction with robots. Based on a general social acceptance of AI devices (Pelau, et al., 2021a; Pelau, et al., 2021b), women will probably follow this behavior, but the process will be slower as in the case of men.

People tend to remain circumspect mostly to scenarios in which robots could possess characteristics that are normally attributed to humans or in which these AI gadgets would become perceived in a similar manner to individuals. All in all, both women and men tend to appreciate the robots' capacity of helping them, but they do not seem to be ready to accept and perceive the AI devices equally as a human being, even though they could either look like one or simulate the behavior of a person. At this point in time, there are some limitations for robots which involve the emotional feelings and abilities such as showing affection.

This topic is of great interest and will remain in the next years, because the technological evolution will continue to impact our lives, both professionally and privately. Many business sectors will be affected and will undergo change through it. From a consumer' perspective, it could be important to raise awareness and willingness to interact and benefit from AI technologies.

\section{References}

Aggarwal, P. and McGill, A.L., 2012.When brands seem human, do humans act like brands? Automatic behavioral priming effects of brand anthropomorphism, Journal of Consumer Research, 39(2), pp.307-323.

Aggarwal, P., Castleberry, S.B., Ridnour, R. and Shepherd, C.D. 2005. Salesperson empathy and listening: Impact on relationship outcomes, Journal of Marketing Theory and Practice, 13(3), pp.16-31.

Ahearne, M., Jelinek, R. and Jones, E. 2007. Examining the effect of salesperson service behavior in a competitive context, Journal of the Academy of Marketing Science, 35(4), pp.603-616.

Ahn, H.K., Kim, H.J. and Aggarwal, P., 2014. Helping fellow beings: Anthropomorphized social causes and the role of anticipatory guilt, Psychological Science, 25(1), pp.224-229.

Bagchi, R. and Ince, E.C., 2016. Is a 70\% forecast more accurate than a 30\% forecast? How level of forecast affects inferences about forecasts and forecasters. Journal of Marketing Research, 53(1), pp.31-45. 
Banacu, C.S., Busu, M., Ignat, R. and Trica C.L. 2019. Entrepreneurial Innovation Impact on Recycling Municipal Waste. A Panel Data Analysis at the EU Level. Sustainability 11(18), Article number: 5125.

Berry, L.L., Carbone, L.P., and Haeckel, S.H., 2002. Managing the total customer experience. MIT Sloan Management Review, 43(3), pp.85-89.

Bowden, L.H., 2009. The process of consumer engagement: a conceptual framework. Journal of Marketing Theory and Practice, 17(1), pp.63-74.

Brakus, J.J., Schmitt, B.H. and Zarantonello, L., 2009. Brand experience: What is it? How is it measured? Does it affect loyalty? Journal of Marketing, 73(3), pp.52-68.

Brodie, R., Ilic, A., Juric, B. and Hollebeek, L., 2011. Consumer engagement in a virtual brand community: an exploratory analysis. Journal of Business Research, 66(1), pp.105-114.

Bruner, G.C., 2019. Marketing Scales Handbook: Multi-Item measures for consumer insight research. GCBII Productions, 10, Texas, USA.

Business Insider, 2015. The Robotics Market Report: The Fast- Multiplying Opportunities in Consumer, Industrial and Office Robots, Business Insider, [online] Available at: $<$ https://www.businessinsider.com.au/growth-statistics-for-robots-market-2015-2> [Accessed 4 April 2021].

Busu, M. 2019. Applications of TQM processes to increase the management performance of enterprises in the Romanian renewable energy sector. Processes, 7(10), Article number: 685.

Cantaragiu, R.E. and Ghinea, V.M., 2020. The Impact of Workaholism on Consumer Food Waste. Amfiteatru Economic, 22(Special Issue No. 14), pp.1140-1158.

Chun, H.E., Diehl, H.K. and MacInnis, D.J., 2017. Savoring an upcoming experience affects ongoing and remembered consumption enjoyment. Journal of Marketing, 81(3), pp.96-110.

Cioaca, S.I., Cristache, S.E., Vuta, M., Marin, E. and Vuta, M., 2020. Assessing the Impact of ICT Sector on Sustainable Development in the European Union: An Empirical Analysis Using Panel Data. Sustainability, 12(2), Article number: 592.

Dabija, D.C. and Babut, R. 2019. Enhancing Apparel Store Patronage through Retailers' Attributes and Sustainability. A Generational Approach. Sustainability 11(17), Article number: 4532.

Ene, I. and Bojescu, I., 2020. Consumer's perception towards the characteristics of artificial intelligence. Proceedings of the 6th BASIQ International Conference on New Trends in Sustainable Business and Consumption (BASIQ). Messina, Italy, pp.730-737.

Fournier, S. and Alvarez, C., 2012. Brands as relationship partners: Warmth, competence, and inbetween. Journal of Consumer Psychology, 22(2), pp.177-185.

Giacobbe, R.W., Jackson, D.W., Jr., Crosby, L.A. and Bridges, C.M., 2006. A contingency approach to adaptive selling behavior and sales performance: Selling situations and salesperson characteristics. Journal of Personal Selling and Sales Management, 26(2), pp.115-142.

Goldkuhl, L. and Styvén, M., 2007. Sensing the scent of service success. European Journal of Marketing, 41(11/12), pp.1297-1305.

Golossenko, A., Pillai, K.G. and Aroean, L., 2020. Seeing brands as humans: Development and validation of a brand anthropomorphism scale. International Journal of Research in Marketing, 37(4), pp.737-755.

Grönroos, C., 2006. Adopting a service logic for marketing. Marketing Theory, 6(3), pp.317-333.

Huang M.H. and Rust R. 2018. Artificial Intelligence in Service. Journal of Service Research, 21(2), pp.155-172.

Iglesias, O., Singh, J.J. and Batista-Foguet, J.M., 2011. The role of brand experience and affective commitment in determining brand loyalty. Journal of Brand Management, 18(8), pp. 570-582.

Iglesias, O., Markovic, S. and Rialp, J., 2019. How does sensory brand experience influence brand equity? Considering the roles of customer satisfaction, customer affective commitment, and employee empathy. Journal of Business Research, 96, pp.343-354. 
Kim, S. and McGill, A.L., 2011. Gaming with Mr. slot or gaming the slot machine? Power, anthropomorphism, and risk perception. Journal of Consumer Research, 38(1), pp.94-107.

Kim, E., Ratneshwar, S.A. and Thorson, E., 2017. Why Narrative Ads Work: An integrated process explanation. Journal of Advertising, 46(2), pp.283-296.

Kim, S. and Baek, T.H., 2018. Examining the antecedents and consequences of mobile app engagement. Telematics and Informatics, 35, pp.148-158.

Kirmani, A., Hamilton, R.W., Thompson, D.V. and Lantzy, S., 2017. Doing well versus doing good: the differential effect of underdog positioning on moral and competent service providers. Journal of Marketing, 81(1), pp.103-117.

Landwehr, J.R., McGill, A.L. and Herrmann, A., 2011. It's got the look: the effect of friendly and aggressive "facial" expressions on product liking and sales. Journal of Marketing, 75, pp.132-146.

Lazarus, R.S., 1991. Emotion and Adaptation. New York: Oxford University Press.

Lin, Y.H., 2015. Innovative brand experience's influence on brand equity and brand satisfaction. Journal of Business Research, 68(11), pp.2254-2259.

Lu, L., Cai, R. and Gursoy, D., 2019. Developing and validating a service robot integration willingness scal. International Journal of Hospitality Management, 80, pp.36-51.

Markovic, S., Iglesias, O., Singh, J.J. and Sierra, V., 2018. How does the perceived ethicality of corporate services brands influence loyalty and positive word-of-mouth? Analyzing the roles of empathy, affective commitment, and perceived quality. Journal of Business Ethics, 148(4), pp.721740 .

Mitrut, C., Balaceanu, C., Gruiescu, M. and Serban, D., 2015. The Macroeconomic Framework of Support Analysis for Sustainable Businesses Development. Amfiteatru Economic, 17(40), pp.10681078.

Pelau, C., Ene, I. and Pop, M.I., 2021a. The impact of artificial intelligence on consumers' identity and human skills. Amfiteatru Economic, 23(56), pp. 33-45.

Pelau, C., Dabija, D.C. and Ene, I. 2021b. What makes an AI device human-like? The role of interaction quality, empathy and perceived psychological anthropomorphic characteristics on the acceptance of artificial intelligence in the service industry. Computers in Human Behaviour. Article Number 106855.

Pelau, C. and Acatrinei, C. 2019. The Paradox of Energy Consumption Decrease in the Transition Period towards a Digital Society. Energies, 12(8), Article number: 1428.

Persado, 2017. Retail CMOS to Invest up to \$100m in AI This Year Improving Audience Engagement to Drive Revenue a Top Priority, [online] Available at. <https:/www.persado.com/pressreleases/retail-cmos-to-invest-up-to-100m-in-ai-this-year-improvingaudience-engagement-todrive-revenue-a-top-priority> [Accessed 3 April 2021].

Pilling, B.K. and Eroglu, S., 1994. An empirical examination of the impact of salesperson empathy and professionalism and merchandise salability on retail buyers' evaluations. Journal of Personal Selling and Sales Management, 14(1), pp.45-58.

Pine, B.J. and Gilmore, J.H., 1998. Welcome to the experience economy. Harvard Business Review, 76, pp.97-105.

Puzakova, M., Kwak, H. and Rocereto, J.F., 2013.When humanizing brands goes wrong: The detrimental effect of brand anthropomorphization amid product wrongdoings. Journal of Marketing, 77(3), pp.81-100.

Schmitt, B., 1999. Experiential marketing. Journal of Marketing Management, 15(1-3), pp.53-67.

Serban, D., Pelau, C. and Dinca V.M. 2019. Panel Data Analysis for Measuring the Impact of E-skills on the Ecological Behavior of Individuals. Economic Computation and Economic Cybernetics Studies and Research, 53(1), pp.57-74.

Simon, F., 2013. The influence of empathy in complaint handling: Evidence of gratitudinal and transactional routes to loyalty. Journal of Retailing and Consumer Services, 20, pp.599-608. 
Stanciu, S., Vîrlănuță, F.O., Vochin, O.A, Ionescu, R.V. and Antohi, V.M., 2019. Fast Moving Consumer Goods (FMCG) Market in Romania. Features and Trends. Amfiteatru Economic, 21(Special Issue No. 13), pp.778-794.

Sun, B., 2006. Invited commentary - technology innovation and implications for customer relationship management. Market, 25 (6), pp.594-597.

van Doorn, J., Mende, M., Noble, S.M., Hulland, J., Ostrom, A.L., Grewal, D. and Petersen, J.A., 2017. Domo Arigato Mr. Roboto: Emergence of Automated Social Presence in Organizational Frontlines and Customers' Service Experiences. Journal of Service Research, 20(1), pp.43-58.

Wang, W., 2017. Smartphones as Social Actors? Social dispositional factors in assessing anthropomorphism. Computers in Human Behavior, 68, pp.334-344.

Wang, J.R., Malthouse, C. and Krishnamurthi, L., 2015. On the go: how mobile shopping affects consumer purchase behavior. Journal of Retailing, 91(2), pp.217-234.

Yao, J., Wang, X. and Liu, Z., 2013. Identification system. Journal of Applied Sciences, 13(21), pp.4477-4482. 